\title{
A Systematic Literature Review of the Impact of Human Resources Management Strategies on Employee's Performance: Role of Job Embeddedness and Organizational Commitment as Mediator Variables
}

\author{
Ohud Awadh Altalhi \\ Faculty of Economics and Administration \\ King Abdulaziz University \\ Umm Al Qura University \\ Meeca - SAUDI ARABIA
}

\begin{abstract}
The present study seeks to examine the effectiveness of the practices of Human Resources (HR) on the performance of employees. It explores how job embeddedness and organizational commitment can have a mediation effect on the relation between the HR practices and staff's performance. Moreover, this study discusses several dimensions of Human Resources Management System (HRMS) such as recruitment, involvement, performance appraisal, compensation, and training. Furthermore, task performance, the efficiency of work and creativity were taken as dimensions of Employee Performance. Data were collected through questionnaires from the participants. The study's population consisted of 503 employees holding different positions in various sectors. Several results were reached by the study, the most significant of which is the finding that there is a positive relationship between the HRMS and Employee Performance. It was also deduced that an indirect partial mediation effect exists between HRMS and Employee Performance through both job embeddedness and organizational commitment.
\end{abstract}

Keywords: Human Resource Management strategies, Employee Performance, Job Embedded, Organizational Commitment.

DOI: $10.7176 / \mathrm{EJBM} / 13-20-07$

Publication date:October $31^{\text {st }} 2021$

\section{Introduction}

The value of human resource management for competitive advantage has been accentuated by international competition, globalization, innovation and technical advances. Human capital has become more important than ever before. It has become even more important than modern technology and material resources. The evolving nature of the job, particularly the technical, operational, and competitive innovations, has meant that companies will still struggle to attract and maintain a sufficient supply of qualified labor market (Allui \& Sahni, 2016).

Oladipo (2011) maintains that having the appropriate resources at the right place and the right time is what guarantees both the success and sustainability of an organization. Both innovative administrators and technology experts represent a main source of competitive advantage. Therefore, at a time of exponential technological growth, it is only the human capital that can play a significant role in all firms' success or failure (Oladipo, 2011). Furthermore, the human element is considered one of the company's key components which must be improved to accomplish the best for it, thereby helping to achieve its goals. The organization does not work efficiently and successfully without taking into careful consideration the human capital and making sacrifices such as spending money and time to select the best (Qatawneh \& Mobaideen, 2017). According to Holtom (2016), employees are the most critical component of an organization and they are one of the capitals which each business manages. The human resources department is responsible for employing and training the company's staff. They are often responsible for using their technical expertise to identify employees' points of strength, calculate salaries, and resolve problems resulting from employees' complaints. In fact, they ensure the staff feel happy when striving to achieve good results and maintain high quality.

Hassan (2016) maintains that there are some HR practices which play a crucial role in enhancing the performance of tasks. They include compensation, staff appraisals, training, career development, and employee's involvement. Furthermore, several other studies that examined the role of HR practices on performance, such as Mahadevan and Mohamed (2014) and Munjuri (2011), suggest that it is important to continue improving these practices to improve employees' performance in an organization._Also, research conducted by Kehoe and Wright (2013) shows that HR practices make positive contribution to the success of the workforce. So, many companies that have long-term goals typically make an effort to re-examine how to handle their human capitals. This is known as the human resource management (HRM) which is a concept that indicates how these organizations attach great importance to the management of their human resources (Tabouli et al., 2016). 
The following section investigates the effect of HRM strategy on employees' performance through both job embeddedness and organizational commitment.

\section{Review of Literature}

\subsection{Human Resource Management Strategies (HRMS):}

One of the major developments taking place in organizations over the recent years is the increasing importance attached to human resources. In recent years, organizations have paid significant attention to human resource practices because they set the regulations governing the duties of employees who are the main driving force in organizational success (Ekwoaba, Ikeije, \& Ufoma, 2015).

The HRM represents a crucial source of sustainable competitiveness since it can lead to the improvement of companies' capabilities (Caliskan, 2010). Additionally, Caliskan (2010) deduced that the manner in which an entity handles its human resources has a direct impact on the success of the organization. According to Mahapatro (2010), human resource management approaches have adopted HRM practices to improve employees' productivity by improving departmental human resource productivity. Generally, human resources departments are responsible for developing, maintaining, and retaining qualified workers to effectively and efficiently achieve the objectives of both the company and the individuals through the HR management (Mahapatro, 2010). According to Alta'an (2013), the effect of HRM on strategic success can strongly influence the relationship between HRM strategies and strategic success. The selection strategy and the training and development strategy ranked first in terms of value. At the second position came the quality evaluation strategy. The third position was occupied by the role review strategy. Furthermore, the study proposed various guidelines such as the necessity to develop interest in the techniques aiming at handling human resources.

\subsection{Involvement:}

Coch and French (1949) are considered pioneers in the study of employees' participation in the workplace. They raised the issue of productivity and performance, believing there is a relationship between employees' involvement in decision making on the one hand and achievement in work, such as rising job satisfaction and productivity, on the other hand. Furthermore, participation in the decision-making process meets the needs of workers thereby improving morale and efficiency at the workplace.

Employees' involvement refers to the degree to which employees are engaged in and committed to the organization they work in and its values (Anitha, 2014). People usually perform their job duties and at the same time engage physically, cognitively, and emotionally at the workplace. This eventually renders the company more intellectually and emotionally connected. As such, employees become able to understand the goals of the company and its values (Anitha, 2014).

Performance management fulfills several significant purposes. Dajani (2015) maintains that employees' involvement positively affects employees' performance. The same point of view is emphasized by Kanten and Sadullah (2012) who argue that there are indications that work involvement is positively relevant to job performance. A study carried out by Darwish and Singh (2013) deduced that employees' performance is dependent on their involvement since companies can enhance a high degree of employees' engagement by developing performance management. Thus, a higher level of employees' performance enables people to give their maximum potential in carrying out their work duties thereby improving the central responsibility for the job.

The study conducted by Dajani (2015) emphasized the significance of the role of the managers who inspire workers and enhance their engagement. Furthermore, the research illustrated that employees' engagement is considered a positive attitude towards the organization and its employee-centered work culture.

\subsection{Performance Appraisal:}

Performance appraisals offer an important means to present documented data about the performance of employees. Accordingly, these appraisals help identify ongoing employment, bonuses, payments, promotion, and pay increases and help improve communication between managers and staff (Ayalew, 2019).

Performance evaluation refers to the systematic evaluation of employees' performance when it comes to the fulfilment of their job duties. This type of assessment aims to promote motivation and self-esteem among employees (Hassan, 2016). Wan et al. (2002) confirmed that value-based performance assessment enhances employees' motivation and commitment, with a significant impact on organizational performance. The key to the organization's success is the willingness of its employees to perform an extra (additional) role and its role in developing the employees' sense of satisfaction while retaining them.

The primary objective of the performance evaluation process is to collect accurate and concrete information about the results and actions of individuals (Maazouzi, 2019). Above all, Maazouzi (2019) argued that perceived employee performance reflects the common belief of the employees regarding both their attitudes and efforts aiming at fulfilling the organization's goals. In addition, the process of assessing performance needs to be based on achieving certain goals. 


\subsection{Compensation and Rewards:}

Reward processes focus on reward strategies and philosophies, and they include arrangements in the form of activities, core values, policies, and processes. They are managed and designed to deliver and maintain suitable types and levels of pay benefits and other kinds of reward (Amanuel, 2017). According to Armstrong (2009), the plan for reward management could describe the advantages of reward management according to the organization's purpose. Also, the strategy of reward should be connected to the organization's business strategies. In order for the business to remain operational, its business strategies should be linked to the reward strategies adopted.

Mathis and Jackson (2010) mentioned that intrinsic incentives may include rewards for completing a project or achieving performance goals. They further stated that many kinds of compensation, both psychological and social, often represent inherent types of incentives. Extrinsic rewards are measurable and take monetary and nonmonetary forms. Direct pay is one concrete aspect of an incentive system, whereby the employer offers monetary rewards for the work done and the performance results accomplished._Njanja (2013) argued that a compensation strategy is necessary for every organization in this era of a competitive and dynamic market. As long as compensation and rewards strategy significantly influence the company's performance, organizations should be aware of the association between rewards and performance by applying performance management programs. Furthermore, Njanja (2013) stated that the effective reward systems should be centered on improving employees' performance.

\subsection{Employee Training and Development:}

Akter (2016) defines employee training as a learning process that seeks to change the skills, behavior, knowledge, and attitudes of workers. Training is vital in enabling workers to use modern techniques and strategies to perform their daily functions. This training helps employees develop their skills and enrich their knowledge to be able to perform their work duties in new environments (Akter, 2016). Employees' development refers to a set of activities that lead to the acquisition of new skills and knowledge and it enhances employees' capabilities (Maimuna \& Rashad, 2013).

Training and development are crucial for the organization as they have a strong effect on the effectiveness and performance of the organization (Ganesh \& Indradevi, 2015). Thus, it is necessary that organizations create effective training programs that promote the long-term success of the firm. According to Ganesh and Indradevi (2015), a clear understanding of a company's policies, goals, job functions, and philosophy through training increases productivity. Based on Ganesh and Indradevi (2015), technical and behavioral training boosts employees' confidence. In order for training and development to be effective, employees need to be closely involved in the organization. The study conducted by Alemayehu (2017) showed that employees had had an average level of performance because they were not satisfied with the current structure and implementation of the training program. According to the study's findings, there is a clear linear correlation between the performance of employees and the design and implementation of training programs in terms of the improvement of workers' capabilities, knowledge, and skills.

Mahapatro (2010) mentioned that the human resources management department of an organization should be involved in employee training and development to gain several benefits, such as the increase of employees' engagement, job satisfaction, employees' morale, capacity to adopt new technology and processes, operation performance, as well as their productivity and creativity. As a result, workers become more knowledgeable, more efficient, more productive, and highly motivated.

\subsection{Relationship between HRM Practices and Employees' Performance:}

Several studies investigating the relationship between HRM activities and employees' performance have been published by many researchers such as Arthur (1994), Huselid (1995), and Guest (1997). Carried out in various sectors and in different countries, these studies revealed that there is an important impact of HRM activities on employees' success. Furthermore, there is a direct relationship between employees' productivity and the company's results. Successful companies consider HRM activities to be a key factor that directly affects employees' output.

\subsection{Organizational Commitment and Dimension:}

Fulmer et al. (2003) suggested that commitment-based HR activities create an internal social climate that motivates workers to act in the best interests of their company rather than in their own individual interests. This perspective is closely aligned with the Strategic Human Resources Management research which indicates that commitmentbased HR strategies have an impact on company's success since they can develop an operational atmosphere that creates workplace attitudes and skills that lead to a strong competitive advantage (Gardner, Van, \& Pierce, 2004).

Meyer and Herscovitch (2001) discussed a recent review of literature addressing commitment and proposed that affective commitment is more related to a wider variety of outcomes and to any measure of results than to continuous or normative commitments. Meyer and Allen (1984) were the first to distinguish between affective and 
continuance commitment. They proposed that affective commitment means personal commitment and participation in the organization whereas continuance commitment refers to employees' willingness to continue working for the organization. Normative commitment refers to an implicit obligation to remain in an organization.

Therefore, commitment can be measured by studying the affective commitment. According to Afroz et al. (2013), affective commitment measures commitment through employees' emotional attachment to an organization. When employees feel they are emotionally connected to the company, they are becoming affectively committed. Moreover, the study clarified that affective commitment influences personal behaviors as well as work experience. In addition, this type of commitment measures the level of general commitment of employees.

Furthermore, workers who are emotionally attached to an organization will be happy at work and will feel they are part of it. Mercurio (2015) argued that affective commitment is linked to job satisfaction. This study further deduced that good performance originates from the emotional attachment that drives employees to work hard. As a result, affective commitment can be used to measure employees' commitment. Thus, the important impact of affective commitment indicates its fruitful outcome.

On the other hand, the lack of affective commitment means that employees are not committed, which consequently impairs performance. Vandenberghe et al. (2004) maintained that when employees invest mentally, emotionally, and physically, their focus is centered on achieving the organizational goals. In addition, affective commitment is strongly correlated with turnover and performance; so, there is a significant relationship between affective commitment and individual and group performance in the workplace.

According to Jaiswal and Dhar (2017), affective commitment acts as a mediator between employee innovation and human resources. Moreover, affective commitment enhances understanding of the impact of HR practices on the level of commitment and provides evidence for the mediation of commitment between these practices and employees' productivity.

\subsection{Job Embeddedness and Dimensions:}

In sociology, the term "embeddedness" was used to describe the mechanism by which social ties affect and limit economic activity (Granovetter, 1985; Uzzi, 1996 \& 1997). According to Terencer, Brooks, \& Thomas (2001), job embeddedness is the degree at which employees are stuck in the organizations. It is a key factor in understanding why people might want to stay in their jobs. The findings show that work embeddedness predicts the main outcomes of both intents to leave and volunteer turnover and explains substantial incremental variation over and above employee satisfaction, organizational engagement, work alternatives and employees' quest (Terencer, Brooks, \& Thomas, 2001). The level at which employees are stuck in the organization can be measured based on three concepts. The measurement could be links, fit, and sacrifice to the organization.

\section{Recommendations and Future Research}

As for the recommendations, the researcher suggested that a system of human resources strategy in organizations must be developed to upgrade the policies and procedures related to the selection, recruitment, compensation, and training of employees. Furthermore, a convenient work environment needs to be available to help increase employees' morale and appreciate respect between managers and employees in order to carry out their work in compliance with the required standards and parameters. The researcher further recommends that all decision makers in human resource management pay more attention to employee-related policies and practices resulting in employees' performance development.

As for the future studies on this topic, researchers can use multiple sources and tools to collect data and do not depend on one tool. Also, further experiments with larger samples may also be carried out. Additionally, researchers can also discuss several dimensions related to employees' performance, such as extra-role employee performance behaviors or organizational environment which can be taken into account. Thus, researchers would extend the study to increase the independent variables to ensure the results are more accurate and credible. In addition, future researchers can use other mediator variables to discuss the relationship between managing human resources and performing employees.

\section{Conclusion}

The present study has highlighted the impact of human resources management strategy on employees' performance by measuring the role of job embeddedness and organizational commitment. The results revealed that HRM practices strongly affect task performance. That is, the HRM practices have a positive relationship with employees' performance. So, it can also directly improve employees' task performance. Better HR practices would result in better employees' performance. Furthermore, job embeddedness and organizational commitment can dynamically play a role as mediating variables for HR practices and strongly affect performance. The results can offer help in understanding the necessity of adopting and applying effective HR practices with the aim to give outstanding performance. Eventually, the researcher recommends that investment in human capital is necessary for continuous innovation and creativity in the organization. Thus, this type of investments will ensure an organization's long- 
term survival and growth.

\section{References}

AFROZ, Neha Kumari\& Nishat. (2013). The Impact of Affective Commitment in Employees Life Satisfaction.

Akter, N. (2016). Employee Training and Employee Development Is the Predictors of Employee Performance; A Study on Garments Manufacturing Sector In Bangladesh. Journal of Business and Management, 18(11), 4857.

Alta'an, H. (2013), The impact of human resource management in achieving strategic success. Al Dananeer Journal, $3,25-44$.

Anitha, J. (2014). Determinants of employee engagement and their impact on employee performance. International Journal of Productivity and Performance Management. 63(3), 308-323.

Armstrong, M., Brown, D., \& Reilly, P. (2009). Increasing the effectiveness of reward management. In EUROPEAN REWARD MANAGEMENT CONFERENCE (Vol. 2).

Arthur, J.B. (1994). Effects of human resource systems on manufacturing performance and turnover. Academy of Management journal, 37(3), 670-687.

Ayalew, G. (2019). The Effects of Selected Human Resource Management on Employees 'Performance; in the Case of Addis Ababa Education Bureau (Doctoral dissertation, Addis Ababa University).

Dajani, M. A. Z. (2015). The impact of employee engagement on job performance and organisational commitment in the Egyptian banking sector. Journal of Business and Management Sciences, 3(5), 138-147.

Ekwoaba, J. O., Ikeije, U. U., \& Ufoma, N. (2015). The Impact of Recruitment and Selection Criteria on Organizational Performance. Employee Performance Appraisal Process, Study Case: Commandant Farrag Secondary School. Karima, Maazouzi

Fulmer, I. S., Gerhart, B., \& Scott, K. S. (2003). Are the 100 best better? An empirical investigation of the relationship between being a "great place to work" and firm performance. Personnel Psychology, 56(4), 965993.

Ganesh, M., \& Indradevi, R. (2015). Importance and effectiveness of training and development. Mediterranean Journal of Social Sciences, 6(1), 334-334.

Gardner, D. G., Van Dyne, L., \& Pierce, J. L. (2004). The effects of pay level on organization - based self esteem and performance: A field study. Journal of occupational and organizational psychology, 77(3), 307322.

Granovetter, M. 1985. Economic action and social structure: The problem of embeddedness. American Journal of Sociology, 91, 481-510.

Guest, D. (2002). Human resource management, corporate performance and employee wellbeing: Building the worker into HRM. The journal of industrial relations, 44(3), 335-358.

Guest, D. E. (1997). Human resource management and performance: a review and research agenda. International journal of human resource management, 8(3), 263-276.

Hassan, S. (2016). Impact of HRM practices on employee's performance. International Journal of Academic Research in Accounting, Finance and Management Sciences, 6(1), 15-22.

Hassan, S., Wright, B. E., \& Park, J. (2016). The role of employee task performance and learning effort in determining empowering managerial practices: Evidence from a public agency. Review of Public Personnel Administration, 36(1), 57-79.

Hassan, Saira. 2016. Impact of HRM Practices on Employee's Performance. International Journal of Academic Research in Accounting, Finance and Management Sciences Vol. 6, No.1, January 2016, pp. 15-22

Holtom, B. C. (2016). Job embeddedness, employee commitment, and related constructs. In Handbook of employee commitment. Edward Elgar Publishing.

Huselid, M.A. (1995). The impact of human resource management practices on turnover, productivity, and corporate financial performance. Academy of management journal, 38(3), 635-672.

Jaiswal, D., \& Dhar, R. L. (2017). Impact of human resources practices on employee creativity in the hotel industry: The impact of job autonomy. Journal of Human Resources in Hospitality \& Tourism, 16(1), 1-21.

Kanten, S. and Sadullah, O., (2012). An empirical research on relationship quality of worklife and work engagement. Procedia-Social and Behavioral Sciences, 62, 360-366.

Kapur, R. (2018). Recruitment and Selection.

Kehoe, R. R., \&Wright, Patrick M. 2013. The Impact of High-Performance Human Resource Practices on Employees' Attitudes and Behaviors. Journal of Management Vol. 39 No. 2, 366-391

Mahadevan, A., Sn Mohamed, F. A. 2014. Impact Of Human Resource Management (HRM) Practices On Employee Performance (A Case Of Telekom Malaysia). International Journal of Accounting \& Business Management Vol. 2 (No.2)

Mathis, R. L., \& Jackson John, H. (2010). Human Resource Management. Edisi Tigabelas.

Mercurio, Z. (2015). Affective Commitment as a Core Essence of Organizational Commitment. Human Resource 
Development Review, 14(4), 389-414.

Meyer, J. P. and L. Herscovitch: 2001, Commitment in the Workplace: Toward a General Model, Human Resource Management Review 11, 299-326.

Munjuri, Mercy Gacheri. 2011. The Effect of Human Resource Management Practices in Enhancing Employee Performance in Catholic Institutions of Higher Learning in Kenya. International Journal of Business Administration Vol. 2, No. 4;

Njanja, L. W., Maina, R. N., Kibet, L. K., \& Njagi, K. (2013). Effect of reward on employee performance: A case of Kenya Power and Lighting Company Ltd., Nakuru, Kenya.

Oladipo, J. A., \& Abdalkader, D. S. (2011). Strategic Human Resource Management and organizational commitment. Human Relations, 40(7), 445-70.

Tabouli, E., Habtoor, N., \& Nashief S., M. (2016). The Impact of Human Resources Management on Employee Performance: Organizational Commitment Mediator Variable. Asian Social Science, 12(9), 176.

Vandenberghe, C., Bentein, K., \& Stinglhamber, F. (2004). Affective commitment to the organization, supervisor, and work group: Antecedents and outcomes. Journal of Vocational Behavior, 64(1), 47-71.

Wan, D., Ong, C. H., \& Kok, V. (2002). Strategic human resource management and organizational performance in Singapore. Compensation \& Benefits Review, 34(4), 33-42. 